\title{
Educational mismatches for second generation migrants. An analysis of applied science graduates in the Netherlands
}

Citation for published version (APA):

Falcke, S., Meng, C., \& Nollen, R. (2016). Educational mismatches for second generation migrants. An analysis of applied science graduates in the Netherlands. Maastricht University, Graduate School of Business and Economics. GSBE Research Memoranda No. 028 https://doi.org/10.26481/umagsb.2016028

Document status and date:

Published: 01/01/2016

DOI:

10.26481/umagsb.2016028

Document Version:

Publisher's PDF, also known as Version of record

\section{Please check the document version of this publication:}

- A submitted manuscript is the version of the article upon submission and before peer-review. There can be important differences between the submitted version and the official published version of record.

People interested in the research are advised to contact the author for the final version of the publication, or visit the DOI to the publisher's website.

- The final author version and the galley proof are versions of the publication after peer review.

- The final published version features the final layout of the paper including the volume, issue and page numbers.

Link to publication

\footnotetext{
General rights rights.

- You may freely distribute the URL identifying the publication in the public portal. please follow below link for the End User Agreement:

www.umlib.nl/taverne-license

Take down policy

If you believe that this document breaches copyright please contact us at:

repository@maastrichtuniversity.nl

providing details and we will investigate your claim.
}

Copyright and moral rights for the publications made accessible in the public portal are retained by the authors and/or other copyright owners and it is a condition of accessing publications that users recognise and abide by the legal requirements associated with these

- Users may download and print one copy of any publication from the public portal for the purpose of private study or research.

- You may not further distribute the material or use it for any profit-making activity or commercial gain

If the publication is distributed under the terms of Article $25 \mathrm{fa}$ of the Dutch Copyright Act, indicated by the "Taverne" license above, 
Swantje Falcke, Christoph Meng, Romy Nollen

Educational mismatches for second generation migrants. An analysis of applied science graduates in the Netherlands

RM/16/028

\section{GSBE}

Maastricht University School of Business and Economics

Graduate School of Business and Economics

P.O Box 616

NL- 6200 MD Maastricht

The Netherlands 


\title{
Educational mismatches for second generation migrants An analysis of applied science graduates in the Netherlands
}

\author{
Swantje Falcke $^{\mathrm{a}}$, Christoph Meng ${ }^{\mathrm{b}}$, Romy Nollen $^{\mathrm{c}}$ \\ ${ }^{a}$ Utrecht University, Kriekenpitplein 21-22, 3584 EC Utrecht, the Netherlands; s.falcke@uu.nl \\ ${ }^{b}$ Maastricht University, P.O. Box 616, 6200 MD, Maastricht, the Netherlands; \\ c.meng@maastrichtuniversity.nl \\ ${ }^{c}$ Ministry of Social Affairs and Employment, Pernassusplein 5, 2511 VX, Den Haag, the Netherlands; \\ romynollen@gmail.com
}

\begin{abstract}
Educational mismatches, i.e. differences between the education attained and required for a job have been found to negatively affect earnings and job satisfaction and thus lead to a lower return to education. In this paper we aim to see whether immigrants are more prone to educational mismatches and unemployment than their native counterparts. Using a cross-sectional data set among recent applied science graduates in the Netherlands between 2006 and 2014 we are able to look at a very homogeneous group where possible differences between immigrants and natives cannot be explained by differences in the quality of education or language capabilities. The results of our multinomial logit regressions suggest that an ethnic penalty in educational mismatches and unemployment exists for western as well as non-western immigrants, being more severe for non-western than western immigrants. Immigrants are less likely to be correctly matched than Dutch natives and more likely to be unemployed, where the likelihood of being unemployed is even higher for non-western immigrants. Furthermore non-western immigrants are more likely to experience a mismatch in content and level than Dutch natives.
\end{abstract}

Keywords: Economics of minorities, skill mismatch, human capital, occupational choice JEL classification: J15, J24

We gratefully acknowledge comments from Kim Broekhoven and Ineke Bijlsma. We also thank Sander Dijksman for support in preparing the data. 


\section{Introduction}

Educational mismatches refer to differences between the education attained and required for a job. Educational mismatches can be divided into vertical and horizontal mismatches. Vertical mismatches are mismatches in level. ${ }^{1}$ Thus, the level of education is higher than required for the job. Horizontal mismatches are mismatches in content. Thus, the field of education does not match the job. Mismatches, and in particular overeducation, can be seen as a huge "brain waste" as the returns to education tend to be lower than for those workers that are correctly matched (Landesmann et al., 2015). Previous evidence shows that mismatches have a negative effect on job satisfaction (Allen and Van Der Velden, 2001; García-Espejo and Ibáñez, 2005; Allen and De Weert, 2007) and earnings (Hartog, 2000; Leuven and Oosterbeek, 2011), the effect on earnings even being stronger for migrants than natives (Joona et al., 2014).

While other determinants of educational mismatches have been analyzed widely, the relationship between migrants and the incidence of these mismatches has not received a lot of attention (Leuven and Oosterbeek, 2011) even though research on this topic has been recently increasing. As migrants are often found to show worse labor market outcomes and suffer ethnic penalties, e.g. in unemployment (Uhlendorff and Zimmermann, 2014), it might be that they also show higher probabilities of experiencing educational mismatches.

In this paper we analyze whether being a second generation (western or non-western) migrant influences the probability of being mismatched and the type of mismatch experienced. We define second-generation immigrants as people born in the Netherlands with at least one of their parents born abroad. Additionally, we include unemployment as another possible outcome in the labor market. We thereby contribute to the existing literature in two ways.

Firstly, we look at a very homogeneous group of natives and migrants. We compare second generation migrants and Dutch natives who graduated in an applied science study in the Netherlands. Thus, we compare individuals who are born in the the same country, grew up in the same educational system and graduated with the same educational degree. Therefore, possible differences in mismatches between migrants and natives are not caused by differences in the quality of the education and to a lesser extent by language difficulties as they all graduated within the same educational system (McGuinness and Byrne, 2015). Only a few studies, i.e. Lindley (2009), Nielsen (2011) and McGuinness and Byrne (2015) have followed this approach. If, after controlling for other factors, a difference between second generation migrants and natives persists, it is called ethnic penalty and might either be due to discrimination (Visintin et al., 2015) or unobservable differences in ability. If discrimination is present and, thus, migrants experience difficulties finding a matching job, they might be more prone to take a job that does not correctly correspond with their qualifications (McGuinness and Byrne, 2015) or need a higher education for the same job to counter this effect (Piracha and Vadean, 2012).

Secondly, previous research on the determinants of overeducation focused on mismatches in level, i.e. vertical mismatches (Hartog, 2000; Robst, 2007). To our knowledge this is the first study that analyzes the relationship between migrant status and educational mismatches not focusing solely on level but also horizontal mismatch and a double mismatch accordingly. Horizontal mismatches may be a problem if occupation-specific skills cannot be transferred to other occupations (Robst, 2007).

Using a pooled cross-sectional data set among recent applied science graduates in the Netherlands between 2006 and 2014, we investigate whether an ethnic penalty in labor market outcomes

\footnotetext{
${ }^{1}$ Vertical mismatches can be divided into over- and undereducation where overeducation refers to a level of education higher than required and undereducation to a level lower than required. In this paper we focus on the effects of overeducation. If we talk about vertical mismatches we refer to overeducation.
} 
exists. Specifically, we analyze whether the migrant status, i.e. Dutch native, western immigrant and non-western immigrant, influences the likelihood of being mismatch or unemployed. The results of our multinomial logit regression suggest that an ethnic penalty in educational mismatches and unemployment exists, being stronger for non-western than western immigrants.

The paper is organized as follows. Section 2 provides an overview on the economic theories and empirical evidence concerning the determinants of educational mismatches in general and the effect of being an immigrant on such a mismatch in particular. In section 3 we describe the data and methodology used in this paper and provide some descriptive statistics, followed by the results in section 4 . Section 5 provides some conclusions.

\section{Education-Job mismatches}

\subsection{The transitions from school to work}

\subsubsection{Theory}

In the transition from school to work, the match between educational and occupation is crucial. Choices made at the beginning of a career may have long-term effects for the employee due to hysteresis. Sub-optimal matches between occupation and graduates may not allow graduates to keep abreast of developments with respect to their core competencies in which they invested (Meng, 2006). The process that matches heterogeneous graduates to heterogeneous jobs within this transition period has received a lot of attention in the theoretical literature (see e.g. Jovanovic, 1979, 1984; Barron and Loewenstein, 1985, Topel, 1986). If the education-job match is not optimal, additional learning by training and job experience are needed to improve or adjust the initial competences acquired during education (Barron and Loewenstein, 1985; Smoorenburg and Velden, 2000; Wolbers, 2003; Badillo-Amador et al., 2005). Indeed the importance to improve or adjust the initial competencies acquired in education has long been emphasized (Becker, 1964; Lynch, 1992; Acemoglu and Pischke, 1998; Pischke, 2000). Additionally, education-job mismatches provide incentives to change jobs Allen and Van Der Velden (2001); Wolbers (2003) as job mismatches form an important cause of job dissatisfaction (see e.g. Burris 1983; Tsang and Leving 1985).

Different economic theories can help to understand the role education plays during the transition stage and the occurrence of a possible mismatch between education and occupation.

Firstly, following the human capital theory, Allen and De Weert (2007) explain that the human capital acquired through education makes graduates more productive in their jobs. Acquiring human capital is done via different channels, of which formal education is the main one. This means that schooling can widen or compress differences in levels of competences. If the education-job match is not optimal, additional learning by training and job experience are needed to improve or adjust the initial competences acquired during education (Badillo-Amador et al., 2005).

Secondly, the searching and matching theory explains overeducation as a temporary situation, caused by imperfect information which disappears with experience in the labor market (Hartog, 2000).

Thirdly, the assignment theory focuses on the demand side of the labor market, where there is an optimal allocation when the most competent worker is assigned to the most complex job, and vice versa. Accordingly, in inefficient labor markets, mismatches can occur because of asymmetric information and search costs.

Fourthly, the technological change theory may explain overeducation in countries with technologically dynamic economics (Hartog, 2000). Educational degrees adjust to technological changes in a country and therefore cohorts that require these skills recently, are considered overeducated compared to earlier cohorts (de Oliveira et al., 2000). 
Lastly, the screening theory treats education purely as a signal of unobserved ability (Hartog, 2000). Accordingly, overeducation should not occur right after graduation but more with time in the labor market when employers account for on-the-job performance in their promotion decisions.

\subsubsection{Empirical evidence}

Next to asymmetric information or search costs, different determinants of educational mismatches have been discussed in the empirical literature. ${ }^{2}$

Firstly, research addressed the effect of individual characteristics on the occurrence of mismatches. Concerning gender, no coherent proof is found, in some studies being female increases the likelihood of obtaining a match in level, and in other studies there is no difference between females and males (Bourdabat and Chernoff, 2010). Wolbers (2003) finds that male graduates have bigger chances on obtaining a vertical mismatch and that the probability of a vertical mismatch is increasing with age. Other individual characteristics on school performance and resume building also affect the chance of being mismatched. Building up your resume before working results in a smaller chance of experiencing mismatches. Mason et al. (2009) find that work experience has a positive effect on the ability of graduates secure employment in 'graduate-level' jobs. Additionally, grades affect the match in a significant way, with a higher grade securing a better match in level(Bourdabat and Chernoff, 2010). Lastly, work experience is another individual characteristic that has been found to positively affect the likelihood to be correctly matched (Bourdabat and Chernoff, 2010).

Secondly, sector-specific characteristics have a strong influence on the occurrence of mismatches, both on vertical and horizontal mismatches. The existing literature makes a distinction between general and specific education, in which occupation-specific competences can provide students with a good basis to start on the labor market, and may result in less experienced discrepancies between demanded and available skills at the start of one's career. On the other hand, education can provide students with competences for further development of their skills, teaching more generic and reflective competences. For these graduates, differences between actual and required skills will decrease over time (Allen and de Vries, 2004). Heijke et al. (2003) find that graduates from occupation-specific programs are more likely to experience a match in content than those in the more general programs. Bourdabat and Chernoff (2010) specify this stating that educational characteristics strongly influence the match, with field specific programs such as health and education showing the least horizontal mismatches.

Lastly, macro-economic variables have an effect on the occurrence of mismatches. Wolbers (2003) finds that high unemployment rates result in the occurrence of more horizontal as well as vertical mismatches. Birchenall (2010) finds that, since unemployment rates differ between sectors, episodes of high unemployment or high vacancies are accompanied by high cross-sectional dispersion. So, the amount of mismatched graduates increases in the sense of higher imbalances, and thus higher dispersion in unemployment and vacancies across the labor market. This also implies that the occurrence of mismatches differs between different educational sectors, since employment rates between the fitting sectors differ.

\subsection{Education-Job mismatches and immigrants}

\subsubsection{Theory}

Chiswick and Miller (2009) review economic theories of educational mismatches for implications of differences for immigrants and natives. Due to differences in language capability and

\footnotetext{
${ }^{2}$ The literature review here focuses on educational mismatches. Previous research (e.g. Carmichael and Woods, 2000) suggests that those factors also determine the probability of unemployment.
} 
educational qualifications, human capital cannot be perfectly transferred across borders which puts immigrants in a relatively worse position than natives (Piracha and Vadean, 2012). The search and adjustment process which causes the temporary overeducation in the job search theory can be expected to be of particular importance for immigrants from origin countries that are very different for the country of destination (Chiswick and Miller, 2009). Education acquired abroad most likely only imperfectly works as a signal and therefore increases the incidence of overeducation for immigrants who hold a foreign diploma.

The assignment theory as well as the technological change theory cannot account for possible differences between natives and immigrants.

It should be noted that the explanations for differences in overeducation for immigrants and natives, suggested by Chiswick and Miller (2009), only applied to first-generation immigrants and often only those that recently arrived. Therefore, these arguments do not apply to our paper as well look at second generation immigrants who obtained the same educational degree as natives.

Piracha and Vadean (2012) offer another explanation that can apply to second-generation immigrants as well as first-generation immigrants. That is, immigrants might be subject to discrimination and accordingly need a higher education for the same job to counter the disadvantaged position caused by discrimination.

\subsubsection{Empirical evidence}

Most studies that analyze the incidences of educational mismatches for immigrants find that skill mismatches are higher among immigrants than natives (Battu and Sloane, 2002; Green et al., 2007; Wald and Fang, 2008; Chiswick and Miller, 2008; Visintin et al., 2015). Green et al. (2007) analyze vertical mismatches in Australia and find that immigrants are more likely to be mismatched than natives with the mismatch probability being even higher for immigrants from countries with non-English speaking background. Wald and Fang (2008) as well find a lack in language capability to increase the likelihood of a mismatch. Using data on workers in Canada, they find that immigrants are more likely to be overeducated where the likelihood is increasing for immigrants from non-English and non-French speaking backgrounds. Chiswick and Miller (2008) analyze the incidence of a vertical mismatch for high-skilled men in the United States and find that it is higher for immigrants than their native counterparts.

While the papers above refer to country studies, Visintin et al. (2015) analyze vertical mismatches in a cross-country study and find that the result of increased likelihood of overeducation for immigrants holds across countries. Using survey data from 86 countries they furthermore find that the effect differs by destination-origin country combinations: African immigrants are always more likely to be overeducated; EU-15 immigrants are more likely to be overeducated when immigrating to another EU-15 country but less likely otherwise; and Central and South American immigrants are more likely to be overeducated in any of the EU-27 countries but less likely in Asia, Africa and Central and South America. Visintin et al. (2015) furthermore finds some evidence that second generation immigrants are more likely to be overeducated.

Studies that focus on second-generation immigrants and are able to specifically differentiate between first- and second-generation immigrants are Battu and Sloane (2002), Joona et al. (2014) and Nielsen (2011). Battu and Sloane (2002) analyze differences in the likelihood of overeducation for ethnic groups in the United Kingdom. They find that only certain non-white ethnic minorities, i.e., Indians, Africans and Chinese face a higher risk of overeducation than Whites. Joona et al. (2014) find an increased probability of overeducation for all immigrants with the probability being even higher for immigrants from regions from which Sweden received a lot of refugees, i.e. Africa, South America and Asia. Expanding the analysis to state dependence in overeducation, they furthermore show that this as well is higher for immigrants than for natives. 
Nielsen (2011) finds a higher incidence of overeducation for immigrants in Denmark. Controlling for the location at which an immigrant obtained their education, they find that being educated in Denmark reduces the risk of overeducation for immigrants.

A study that compares immigrants and natives who have the same educational qualification is Lindley (2009). Analyzing the likelihood of overeducation among graduates in Great Britain, Lindley (2009) finds that Black African, other non-white and Indian men as well as Indian and Pakistani/Bangladeshi women are more likely to be overeducated that their native counterparts.

Piracha et al. (2012) analyze vertical mismatches for immigrants without comparing them to their native counterparts. Using survey data from immigrants coming to Australia, they analyze the determinants of mismatches for immigrants. They find that being mismatched in the country of origin increases the probability to experience a mismatch in Australia.

Educational mismatch always refers to formal skills, even though skills may also be gained by informal means, i.e. on-the-job experience. Some authors therefore suggest that looking at skill mismatches instead would be a more suitable measure of a mismatch (McGuinness and Byrne, 2015). However, skills are more difficult to measure (Visintin et al., 2015). A study that analyzes skill mismatches and the effect of immigrant status is McGuinness and Byrne (2015). Studying immigrants who graduated from university in the EU-15 countries, they find only little evidence that overeducation is higher among immigrants compared to natives. However, they find a higher incidence of over-skilling arises among female immigrants with short duration of domicile. They analyze immigrants in tertiary education and previous research shows that ethnic penalties in labor market outcomes are decreasing in educational level (Nielsen, 2011).

Heath et al. (2008) reviewed country-studies on unemployment incidences for immigrants. They conclude that, across all countries, immigrants experience an ethnic penalty in unemployment, i.e. they have a higher risk in unemployment compared to their native counterparts.

\section{Data and Methodology}

The data used in this study is the applied science monitor. The applied science monitor is an annual survey carried out by the Dutch Research Center for Education and Labor Market (ROA). This monitor samples applied science graduates and includes questions on their educational background and labor market outcomes. The sample consists of approximately 20,000 applied science graduates per year, which corresponds to a response rate of 40 percent. The sampling frame are the administrative databases of universities of applied science, which contain data on graduate date, type of program and field of study. 95 percent of the graduates in the Netherlands are enrolled at the institutes that take part in the survey. ${ }^{3}$ Graduates are approached by mail and e-mail approximately 1.5 years after graduation. Graduates from the Arts sector are excluded in our analyses as they have a different questionnaire and thus, cannot be compared with the other sectors.

The applied science graduates are asked which level of education and which education is content-wise needed for their current position. Based on this, the type of mismatch (no mismatch vs. vertical vs. horizontal vs. double mismatch) is identified. Also, we introduce "being unemployed" as an additional labor market outcome.

In addition, we restrict the sample according to the following factors: Firstly, we look only at graduates with a Bachelor education (excluding graduates from Master studies) because the percentage with an applied science master is very low. Secondly, we focus on full-time students. Part-time students have quite different features than full-time student and often already had a

\footnotetext{
${ }^{3}$ A few, mostly private institutes, are not connected to the ROA monitor.
} 
job and usually remain in this job after graduation. Thirdly, we exclude students that are return migrants by looking only at those that live and work in the Netherlands at the time the survey is carried out. Lastly, in order to reduce linguistic and cultural differences to a minimum we only look at people born in the Netherlands. Thus, we compare second generation immigrants to Dutch natives.

To examine mismatches we use a self-evaluation measure of the match between a graduate's job and education. ${ }^{4}$ The different educational mismatch outcomes are determined by different questions in the applied science monitor survey where respondents were asked to indicate the education level required by the employer as well as whether their current job is in the same field as their education. Comparing the educational level required for the job to the respondents' actual educational level, a person is defined as vertically mismatched if the education is higher than the level required for their current job. When asked about the study field required for the job, respondents could use the following response categories: exclusively my own study field, my own or a related study field, a completely different study field, no specific study field. If a respondent indicated one of the former two they are classified as correctly matched with respect to the content and if they indicated one of the latter two they are classified as being horizontally mismatched. If a respondent showed a vertical as well as horizontal mismatch they are classified as experiencing a double mismatch.

Our dependent variable is a categorical variable that indicates whether a person experiences (1) no mismatch, (2) a horizontal mismatch, (3) a vertical mismatch, (4) a double mismatch (horizontal and vertical) or (5) is unemployed. A person is defined as unemployed if currently looking for a job and working less than 12 hours a week. ${ }^{5}$

Our main independent variable captures whether a person is a second generation immigrant or not, differentiating between Dutch natives, western and non-western second generation immigrants. A second generation immigrant is a person born in the Netherlands where at least one of the parents was born abroad. Following the definition of the Dutch Bureau of Statistics, non-western migrants are from Africa, Latin-America, Asia (excluding Indonesia and Japan) and Turkey and western migrants are, accordingly, from Europe (excluding Turkey), North America, Oceania, Indonesia or Japan. ${ }^{6}$ As we restrict our analysis to second generation migrants born in the Netherlands, and in order to shorten the terms describing them, in the remainder of the paper we refer to western second generation immigrants as western migrants and non-western second generation migrants as non-western migrants.

In the analysis in the next section, we control for several variables which we expect, based on the literature review in section 2.1, to possible have an effect. Firstly, we control for individual characteristics, i.e. age and gender. Age of the respondent is measured at the moment the survey was conducted. As previous research has shown contradictory evidence concerning the effect of age on the probability of a mismatch, we allow for a non-linear relationship between age and mismatch by additionally including age-squared. By controlling for gender we control for the different employment profiles of men and women. Secondly, we control for school performance and resume building. We control for the average final grade the respondent received for a applied science study as well as the highest prior education of the respondent. ${ }^{7}$ By including a set of

\footnotetext{
${ }^{4}$ Using a self-evaluated measure is also referred to as the subjective method. Educational mismatches have also been measures via expert classification (objective method) and, for overeducation, in average years of schooling (empirical method). See e.g. Piracha and Vadean (2012) or Visintin et al. (2015) for a discussion of the different methods.

${ }^{5}$ This definition follows the definition of unemployment by the Dutch Bureau of Statistics (CBS).

${ }^{6}$ https://www.cbs.nl/nl-nl/onze-diensten/methoden/begrippen

${ }^{7}$ Prior education is controlled for with a categorical variables where the respondents could indicate their highest prior education, i.e. general secondary education, pre-university secondary education, school-based/work-based
} 
Table 1: Incidence of mismatches

\begin{tabular}{lccccccccc}
\hline & \multicolumn{2}{c}{ Total } & \multicolumn{2}{c}{ Dutch } & \multicolumn{2}{c}{ Western } & \multicolumn{2}{c}{$\begin{array}{c}\text { Non-western } \\
\text { immigrants }\end{array}$} \\
& & & & & \multicolumn{2}{c}{ immigrants } \\
Mismatch & Obs. & $\%$ & Obs. & $\%$ & Obs. & $\%$ & Obs. & $\%$ \\
\hline \hline & & & & & & & & \\
No mismatch & 52243 & 63.79 & 48420 & 64.55 & 1899 & 58.16 & 1924 & 52.97 \\
Horizontal mismatch & 9066 & 11.07 & 8070 & 10.76 & 490 & 15.01 & 506 & 13.93 \\
Vertical mismatch & 9486 & 11.58 & 8794 & 11.72 & 337 & 10.32 & 355 & 9.77 \\
Double mismatch & 6943 & 8.48 & 6196 & 8.26 & 326 & 9.98 & 421 & 11.59 \\
Unemployed & 4166 & 5.09 & 3527 & 4.7 & 213 & 6.52 & 426 & 11.73 \\
& & & & & & & & \\
\hline
\end{tabular}

variables on other experiences during the education, we attempt to control for informal skills students might acquire on the job which can influence an educational mismatch as discussed in section 2. The variables concern experience within boards and committees, internships in the Netherlands and abroad, education abroad and other relevant experience. Thirdly, we control for the study fields where each study program is assigned to one of 27 categories. $^{8}$

The final sample consists of 77,781 observations from the years 2006 to 2014 of which 8.5 percent are immigrants (4.5 percent western and 4 percent non-western immigrants).

Table 1 displays the incidences of mismatches and unemployment of the whole data set for Dutch natives, western immigrants and non-western immigrants separately. ${ }^{9}$ Among all groups the majority is correctly matched. However, the share is the highest for Dutch natives and the lowest for non-western immigrants with a difference of 11.6 percentage points. When looking at double mismatches as well as unemployment, a smaller share of Dutch natives is experiencing one of the two. Among the immigrant groups non-western immigrants show higher occurrences for both outcomes. The effect is particularly strong for unemployment. Among non-western immigrants in the sample, 11.7 percent are unemployed, compared to 6.52 percent of western immigrants and 4.7 percent of Dutch natives. Western immigrants show the highest occurrence of only horizontal mismatches and Dutch natives the lowest. When looking at vertical mismatches only, it is Dutch natives who show the highest occurrence and non-western immigrants the lowest.

In order to capture the effect of migrant status on educational mismatches and unemployment a multinomial logistic regression is estimated as there are five possible labor market outcomes (No mismatch, horizontal mismatch, vertical mismatch, double mismatch and unemployment):

$$
\operatorname{Pr}\left(\text { LabourMarketOutcome }_{i}\right)=\text { MigStatus }_{i}+X_{i}+\varepsilon_{i}
$$

where $i$ is the individual, MigStatus $i$ is the migrant status of the individual (Dutch native, western immigrant, non-western immigrant) and $X_{i}$ captures the control variables mentioned above.

secondary vocational education, higher vocational education or other.

${ }^{8}$ Those 27 categories are: educational studies, educational studies in general subjects, teacher occupational subjects, pedagogic, art, social and cultural education, communicational studies, journalism, business administration, marketing and commercial economics, accountancy and finance, business economics and human resource management, law, environment studies, computer science, mechanical engineering, electrical engineering, chemistry, civil engineering, agriculture, nursery and medical diagnostics, physiotherapy, social work, leisure and facility management, logistics, remaining, university: education.

${ }^{9}$ Summary statistics of the control variables can be found in the Appendix. 


\section{Results}

In the following section we present the results of the multinomial logistic regression to shed light on whether an ethnic penalty exists in educational mismatches and unemployment. As discussed in section 2, differences in the incidence of educational mismatches could be due to other factors but immigrant status. Accordingly, we account for different observable factors, namely age (and $\mathrm{age}^{2}$ ), gender, average grade, highest education before this study, field of study and variables capturing experience. We furthermore add regional and year dummies to account for regional and time differences. ${ }^{10}$

Table 2 presents the results of the multinomial logit regressions reported in average marginal effects. We find that being an immigrant, western or non-western, decreases the likelihood of being correctly matched compared to Dutch natives. The coefficient for non-western immigrants is bigger than that for western immigrants. However, the difference between the two coefficients is statistically insignificant. ${ }^{11}$

The migrant status also matters when it comes to single mismatches, i.e. either horizontal or vertical mismatches. Compared to Dutch natives western immigrants are more likely to experience a horizontal mismatch, whereas no difference exists between Dutch natives and nonwestern immigrants. Concerning vertical mismatches, non-western immigrants are less likely to experience a vertical mismatch than Dutch natives, whereas there is no difference between western immigrants and Dutch natives.

Being a non-western immigrant increases the probability of experiences a mismatch in level as well as content, i.e. a double mismatch. Being a western immigrant does not change this likelihood compared to Dutch natives.

The results in column (2) to (4) suggest that being a second-generation western immigrant only increases the likelihood of a horizontal mismatch. Second-generation western immigrants seem to not be more likely overeducated than Dutch natives. Furthermore, the results in column (2) to (4) suggest that being a second generation non-western immigrant increases the likelihood of experiencing a double mismatch, i.e. a mismatch in level and content. As non-western immigrants are more likely to be double mismatches, the decreased likelihood of experiencing a single vertical mismatch (column 3) is difficult to interpret as it can be due to non-western immigrants only experiencing a vertical mismatch when experiencing a horizontal mismatch at the same time.

Being an immigrant furthermore increases the likelihood of being unemployed, independent of being a western or non-western immigrant. The coefficient is higher for non-western than western immigrants and the difference between the coefficients is significant. Thus, being a second-generation immigrant increases the likelihood of being unemployed, even more so for non-western than western immigrants.

Concerning the control variables, age significantly affects all labor market outcomes and the older the respondent the worse for his or her labor market outcomes. If age increases, graduates are less likely to be correctly matched and more likely to be horizontally or double mismatched as well as unemployed. Only the likelihood of a single vertical mismatch decreases with age.

Gender affects the likelihood of a match but not the likelihood of being unemployed. Compared to their male counterparts, female applied science graduates are less likely to be correctly

\footnotetext{
${ }^{10}$ In this paper we report results where we control for regional effects on provincial level. The results are robust to changing this to a less detailed (North, East, South, West) or more detailed (RPA-clusters) regional level.

${ }^{11}$ See the marginsplot in the Appendix
} 
Table 2: Results

\begin{tabular}{|c|c|c|c|c|c|}
\hline & $\begin{array}{l}(1) \\
\text { No }\end{array}$ & $\begin{array}{c}(2) \\
\text { Horizontal }\end{array}$ & $\begin{array}{c}(3) \\
\text { Vertical }\end{array}$ & $\begin{array}{c}(4) \\
\text { Double }\end{array}$ & $\begin{array}{c}(5) \\
\text { Unemployed }\end{array}$ \\
\hline Western immigrant & $\begin{array}{c}-0.0281^{* * *} \\
(0.0082)\end{array}$ & $\begin{array}{c}0.0179^{* * *} \\
(0.0056)\end{array}$ & $\begin{array}{l}-0.0079 \\
(0.0056)\end{array}$ & $\begin{array}{c}0.0057 \\
(0.0049)\end{array}$ & $\begin{array}{c}0.0123^{* * *} \\
(0.0042)\end{array}$ \\
\hline Non-western immigrant & $\begin{array}{c}-0.0527^{* * *} \\
(0.0079)\end{array}$ & $\begin{array}{c}0.0075 \\
(0.0051)\end{array}$ & $\begin{array}{c}-0.0282^{* * *} \\
(0.0047)\end{array}$ & $\begin{array}{c}0.0160^{* * *} \\
(0.0048)\end{array}$ & $\begin{array}{c}0.0574^{* * *} \\
(0.0051)\end{array}$ \\
\hline \multicolumn{6}{|l|}{ Reference group: Dutch natives } \\
\hline Age & $\begin{array}{c}-0.0133^{* * *} \\
(0.0010)\end{array}$ & $\begin{array}{c}0.0064^{* * *} \\
(0.0006)\end{array}$ & $\begin{array}{c}-0.0045^{* * *} \\
(0.0007)\end{array}$ & $\begin{array}{c}0.0060^{* * *} \\
(0.0006)\end{array}$ & $\begin{array}{c}0.0054^{* * *} \\
(0.0004)\end{array}$ \\
\hline Female & $\begin{array}{c}-0.0326^{* * *} \\
(0.0041)\end{array}$ & $\begin{array}{c}-0.0105^{* * *} \\
(0.0026)\end{array}$ & $\begin{array}{c}0.0283^{* * *} \\
(0.0028)\end{array}$ & $\begin{array}{c}0.0140^{* * *} \\
(0.0024)\end{array}$ & $\begin{array}{c}0.0008 \\
(0.0020)\end{array}$ \\
\hline \multicolumn{6}{|l|}{ Reference group: Male } \\
\hline GPA & $\begin{array}{c}0.0285^{* * *} \\
(0.0014)\end{array}$ & $\begin{array}{l}-0.0013 \\
(0.0010)\end{array}$ & $\begin{array}{c}-0.0101^{* * *} \\
(0.0010)\end{array}$ & $\begin{array}{c}-0.0125^{* * *} \\
(0.0009)\end{array}$ & $\begin{array}{c}-0.0047^{* * *} \\
(0.0007)\end{array}$ \\
\hline \multicolumn{6}{|l|}{ Highest education: } \\
\hline Pre-university secondary education & $\begin{array}{c}0.0245^{* * *} \\
(0.0048)\end{array}$ & $\begin{array}{c}0.0024 \\
(0.0033)\end{array}$ & $\begin{array}{c}-0.0086^{* * *} \\
(0.0031)\end{array}$ & $\begin{array}{c}-0.0120^{* * *} \\
(0.0030)\end{array}$ & $\begin{array}{c}-0.0064^{* * *} \\
(0.0024)\end{array}$ \\
\hline School-based/Work-based & $0.0262^{* * *}$ & $-0.0228^{* * *}$ & $0.0363^{* * *}$ & $-0.0277^{* * *}$ & $-0.0120^{* * *}$ \\
\hline secondary vocational education & $(0.0042)$ & $(0.0027)$ & $(0.0031)$ & $(0.0024)$ & $(0.0019)$ \\
\hline Higher vocational education & $\begin{array}{c}0.0598^{* * *} \\
(0.0089)\end{array}$ & $\begin{array}{c}-0.0143^{* *} \\
(0.0060)\end{array}$ & $\begin{array}{c}-0.0120^{* *} \\
(0.0061)\end{array}$ & $\begin{array}{c}-0.0247^{* * *} \\
(0.0051)\end{array}$ & $\begin{array}{c}-0.0088^{* *} \\
(0.0041)\end{array}$ \\
\hline Other & $\begin{array}{l}0.0388^{* *} \\
(0.0162)\end{array}$ & $\begin{array}{c}0.0004 \\
(0.0114)\end{array}$ & $\begin{array}{l}-0.0032 \\
(0.0109)\end{array}$ & $\begin{array}{c}-0.0296^{* * *} \\
(0.0083)\end{array}$ & $\begin{array}{l}-0.0064 \\
(0.0068)\end{array}$ \\
\hline \multicolumn{6}{|c|}{ Reference group: General secondary education } \\
\hline Experience during study: & $0.0344^{* * *}$ & $-0.0072^{* * *}$ & $0.0093^{* * *}$ & $-0.0260^{* * *}$ & $-0.0105^{* * *}$ \\
\hline Other (yes) & $(0.0033)$ & $(0.0022)$ & $(0.0022)$ & $(0.0020)$ & $(0.0016)$ \\
\hline Experience during study: & $0.0205^{* * *}$ & $0.0142^{* * *}$ & $-0.0217^{* * *}$ & $-0.0051^{*}$ & $-0.0079^{* * *}$ \\
\hline Student/board committee (yes) & $(0.0043)$ & $(0.0029)$ & $(0.0029)$ & $(0.0026)$ & $(0.0020)$ \\
\hline Experience during study: & -0.0104 & $0.0181^{* * *}$ & $-0.0197^{* * *}$ & -0.0026 & $0.0145^{* * *}$ \\
\hline Education abroad (yes) & $(0.0066)$ & $(0.0042)$ & $(0.0045)$ & $(0.0036)$ & $(0.0034)$ \\
\hline Experience during study: & 0.0004 & $0.0061^{*}$ & -0.0031 & $-0.0067^{* *}$ & 0.0033 \\
\hline Internship abroad (yes) & $(0.0049)$ & $(0.0034)$ & $(0.0032)$ & $(0.0029)$ & $(0.0024)$ \\
\hline Experience during study: & $0.0345^{* * *}$ & 0.0019 & $-0.0260^{* * *}$ & -0.0077 & -0.0028 \\
\hline Internship in the Netherlands (yes) & $(0.0084)$ & $(0.0048)$ & $(0.0065)$ & $(0.0048)$ & $(0.0037)$ \\
\hline Year dummies & yes & yes & yes & yes & yes \\
\hline Sector dummies & yes & yes & yes & yes & yes \\
\hline Regional dummies & yes & yes & yes & yes & yes \\
\hline Observations & 77,781 & 77,781 & 77,781 & 77,781 & 77,781 \\
\hline
\end{tabular}

Robust standard errors in parentheses, ${ }^{* * *} \mathrm{p}<0.01,{ }^{* *} \mathrm{p}<0.05,{ }^{*} \mathrm{p}<0.1$

We control for age, gender, average grade, prior education, sectors of study, other experience, region-specific effects, year-specific effects (see Appendix for the full output) 
matched. Furthermore, they are more likely to experience a double mismatch or a single vertical mismatch. However, being female decreases the likelihood of a single horizontal mismatch.

In line with the previous literature discussed in section 2, a higher average grade positively affects a respondent's labor market outcomes. A better grade increases the likelihood of being correctly matched and decreases the likelihood of a single vertical mismatch, double mismatch or unemployment. The average grade does not affect the likelihood of a single horizontal mismatch.

The general secondary education is the lowest of the categories for education acquired before the applied science studies of the graduates in our data set. Compared to general secondary education, graduates with pre-university secondary education, school-based/work-based secondary vocational education and higher vocational education are more likely to be correctly matched and less likely to be double mismatch or unemployed. Students with higher vocational education are also more likely to experience both types of single mismatches compared to graduates with general secondary education. Graduates with pre-university secondary education are also less likely than students with general secondary education to experience a vertical mismatch. However, they are more likely to be single horizontally mismatched. The opposite is the case for the likelihood of single mismatches for school-based/work-based secondary vocational education graduates compared to those with general secondary education as they are less likely to be single horizontally mismatched but more likely to be single vertically mismatched.

Most of the variables capturing additional experiences during the studies have a positive effect on labor market outcomes, in line with previous research discussed in section 2. However, the effect seems to be stronger for experience acquired within the Netherlands than abroad. Being a member of a student committee, doing an internship in the Netherlands and other experiences increases the likelihood of being correctly matched. Acquiring some education abroad or doing an internship in another country, however, does not affect the likelihood of a correct match. Experience in a student committee and other experience also decrease the likelihood of being double mismatched or unemployed, whereas an internship in the Netherlands does not affect it. If anything, acquiring some of the education abroad seems to have a negative effect on labor market outcomes as it increases the likelihood of single mismatch as well as unemployment and only decreases the likelihood of a single vertical mismatch. Having done an internship abroad only shows weak effects. At a ten percent significance level it increases the likelihood of a single horizontal mismatch and at a five percent significance level it decreases the likelihood of a double mismatch. As mentioned above doing an internship in the Netherlands increases the likelihood of being correctly matched. Furthermore, the effect is insignificant for the other outcomes but a significant and negative effect on the likelihood of a single vertical mismatch.

\section{Conclusion and Discussion}

In this paper we analyze whether being an immigrant increases the likelihood of being educationally mismatched or unemployed and the type of mismatch experiences. We use crosssectional data on recent applied science graduates in the Netherlands from 2006 to 2014. By comparing second generation immigrants with Dutch natives who finished the same educational level in the same country, we eliminate possible differences due to differences in the quality of the education or in language capabilities.

Our results show that an ethnic penalty in educational mismatch and unemployment exists, being more sever for non-western than western immigrants. This ethnic penalty is in particular visible in the decreased likelihood of a correct match for immigrants in general, the increased likelihood of non-western immigrants to experience a double mismatch and the increased likelihood of unemployment for both types of immigrants with the effect being even stronger for non-western immigrants. Furthermore, we find that other factors such as differences in study 
choices, pre-higher educational paths, GPA or differences in resume building during the study can only marginally explain parts of the ethnic penalty. Previous empirical studies suggest that migrants show worse labor market outcomes and are more likely to be mismatches. However, many of these studies have been criticized for studying a heterogeneous group where differences in the incidence of mismatches may be due to differences in the quality of education or language capability. Our results suggest that the ethnic penalty found in previous studies remains when comparing migrants who grew up in the same country and graduated in the same educational system.

Previous research has shown that educational mismatches reduce the returns to education, i.e. earning and job satisfaction. It is therefore important that policy makers try to reduce the ethnic penalty in educational mismatches and unemployment.

This paper suggests that an ethnic penalty in labor market outcomes remains when studying a rather homogeneous group and controlling for other determinants of educational mismatches and unemployment. Still, it should be noted that we cannot ultimately say what causes the ethnic penalty.

The observed ethnic penalty can be either due to discrimination or differences in unobservable differences in ability. By controlling for various individual characteristics we aim to control for many differences in ability. After controlling for these characteristics we still find a clear impact of being an immigrant on the probability of experiences a mismatch. Unfortunately, this paper cannot fully identity what part of the effect is due to discrimination. However, recent experimental studies show that within the hiring process ethnical discrimination is present (Bertrand and Mullainathan, 2004; Drydakis and Vlassis, 2010; Carlsson and Rooth, 2007; Oreopoulosa, 2011; Kaas and Manger, 2012). These findings suggest that part of the ethnic penalty found in this paper is caused by discrimination.

Next to ability, discrimination and the individual characteristics we control for, other personal traits such as an individual's attitude during a job interview might influence the likelihood of being mismatched or unemployed as well. Unfortunately, this study cannot, due do data limitations, take personal traits into account.

The different categories of a mismatch may vary in themselves. I.e., a person can be horizontally mismatched in a completely different study field or no specific study field. While it goes beyond the scope of this paper, future research might explore the distribution for migrants and natives within the labor market outcome categories in this paper. 


\section{References}

Acemoglu, D. and Pischke, J.-S. (1998). Why do firms train? theory and evidence. The Quarterly Journal of Economics, 113(1):79-119.

Allen, J. and de Vries, R. (2004). Determinants of skill mismatches: the role of learning environment, the match between education and job and working experience. Challenge, 25:26.

Allen, J. and De Weert, E. (2007). What do educational mismatches tell us about skill mismatches? a cross-country analysis. European Journal of Education, 42(1):59-73.

Allen, J. and Van Der Velden, R. (2001). Educational mismatches versus skill mismatches: Effects on wages, job satisfaction, and on-the-job search. Oxford Economic Papers, 53(3):434452 .

Badillo-Amador, L., García-Sánchez, A., and Vila, L. E. (2005). Mismatches in the spanish labor market: Education vs. competence match. International Advances in Economic Research, 11(1):93-109.

Barron, J. and Loewenstein, M. (1985). On employer specific information and internal labor markets. Southern Economic Journal, 52:431-445.

Battu, H. and Sloane, P. (2002). To what extent are ethnic minorities in britain over-educated? International Journal of Manpower, 23(3):192-208.

Becker, G. (1964). Human capital: A theoretical and empirical analysis with special reference to education. Technical report, NBER New York.

Bertrand, M. and Mullainathan, S. (2004). Are emily and greg more employable than lakisha and jamal? a field experiment on labor market discrimination. The American Economic Review, 94(4):991-1013.

Birchenall, J. (2010). A competitive theory of mismatch.

Bourdabat, B. and Chernoff, V. (2010). The determinants of education-job match among canadian university graduates. Scientific Publication 2010s-14.

Burris, V. (1983). The social and political consequences of overeducation. American Sociological Review, 48:454-467.

Carlsson, M. and Rooth, D.-O. (2007). Evidence of ethnic discrimination in the swedish labor market using experimental data. Labour Economics, 14(4):716-729.

Carmichael, F. and Woods, R. (2000). Ethnic penalties in unemployment and occupational attainment: Evidence for britain. International Review of Applied Economics, 14(1):71-98.

Chiswick, B. R. and Miller, P. W. (2008). Why is the payoff to schooling smaller for immigrants? Labour Economics, 15(6):1317-1340.

Chiswick, B. R. and Miller, P. W. (2009). The international transferability ofimmigrants' human capital. Economics of Education Review, 28:162-169.

de Oliveira, M. M., Santos, M. C., and Kiker, B. F. (2000). The role of human capital and technological change in overeducation. Economics of Education Review, 19(2):199-206. 
Drydakis, N. and Vlassis, M. (2010). Ethnic discrimination in the greek labour market: occupational access, insurance coverage and wage offers. The Manchester School, 78(3):201-218.

García-Espejo, I. and Ibáñez, M. (2005). Educational-skill matches and labour achievements among graduates in spain. European Sociological Review, 22(2):141-156.

Green, C., Kler, P., and Leeves, G. (2007). Immigrant overeducation: Evidence from recent arrivals to australia. Economics of Education Review, 26(4):420-432.

Hartog, J. (2000). Over-education and earnings: where are we, where should we go? Economics of education review, 19(2):131-147.

Heath, A. F., Rothon, C., and Kilpi, E. (2008). The second generation in western europe: Education, unemployment, and occupational attainment. Annual Review of Sociology, 34(1):211235 .

Heijke, H., Meng, C., and Ris, C. (2003). Fitting to the job: the role of generic and vocational competencies in adjustment and performance. Labour Economics, 10(2):215-229.

Joona, P. A., Gupta, N. D., and Wadensjö, E. (2014). Overeducation among immigrants in sweden: incidence, wage effects and state dependence. IZA Journal of Migration, (3).

Jovanovic, B. (1979). Job matmatch and the theory of turnover. Journal of Political Economy, $87: 1246-1260$.

Jovanovic, B. (1984). Matmatch, turnover and unemployment. Journal of Political, 82:299-312.

Kaas, L. and Manger, C. (2012). Ethnic discrimination in germany's labour market: a field experiment. German Economic Review, 13(1):1-20.

Landesmann, M., Leitner, S., and Jestl, S. (2015). Migrants and natives in eu labour markets: Mobility and job-skill mismatch.

Leuven, E. and Oosterbeek, H. (2011). Overeducation and mismatch in the labor market. Handbook of the Economics of Education, 4:283-326.

Lindley, J. (2009). The over-education of uk immigrants and minority ethnic groups: Evidence from the labour force survey. Economics of Education Review, 28(1):80-89.

Lynch, L. (1992). Private sector training and earnings of young workers. American Economic Review, 82:299-312.

Mason, G., Williams, G., and Cranmer, S. (2009). Employability skills initiatives in higher education: what effects do they have on graduate labour market outcomes? Education Economics, 17(1):1-30.

McGuinness, S. and Byrne, D. (2015). Born abroad and educated here: examining the impacts of education and skill mismatch among immigrant graduates in europe. IZA Journal of Migration, (4).

Meng, C. (2006). Discipline-specific or academic? acquisition, role and value of higher education competencies. ROA Dissertation, Research Centre for Education and the Labor Market, Maastricht.

Nielsen, C. P. (2011). Immigrant over-education: evidence from denmark. Journal of Population Economics, 24(2):499-520. 
Oreopoulosa, P. (2011). Why do skilled immigrants struggle in the labor market? a field experiment with thirteen thousand resumes. American Economic Journal: Economic Policy, $3(4): 148-171$.

Piracha, M., Tani, M., and Vadean, F. (2012). Immigrant over-and under-education: The role of home country labour market experience. IZA Journal of Migration, 1(1):1-21.

Piracha, M. and Vadean, F. (2012). Migrant educational mismatch and the labour market. IZA Discussion Paper No. 6414.

Pischke, J.-S. (2000). Continuous training in germany. Technical Report 137, IZA Discussion Paper.

Robst, J. (2007). Education and job match: The relatedness of college major and work. Economics of Education Review, 26(4):397-407.

Smoorenburg, M. v. and Velden, R. v. d. (2000). The training of school-leavers complementarity of substitution? Economics of Education Review, 19:207-2017.

Topel, R. (1986). Job mobility, search and earnings growth. Research in Labor Economics, 8:199-233.

Tsang, M. and Leving, H. (1985). The economics of overeducation. Economics of Education Review, 4:93-104.

Uhlendorff, A. and Zimmermann, K. F. (2014). Unemployment dynamics among migrants and natives. Economica, 81(322):348-367.

Visintin, S., Tijdens, K., and van Klaveren, M. (2015). Skill mismatch among migrant workers: evidence from a large multi-country dataset. IZA Journal of Migration, 4(1).

Wald, S. and Fang, T. (2008). Overeducated immigrants in the canadian labour market: Evidence from the workplace and employee survey. Canadian Public Policy, 34(4):457-479.

Wolbers, M. H. J. (2003). Job mismatches and their labour-market effects among school-leavers in europe. European Sociological Review, 19(3):249-266. 


\section{Appendix}

7.1. Appendix A

Table 3: Summary statistics, all variables

\begin{tabular}{|c|c|c|c|c|c|c|}
\hline \multicolumn{2}{|c|}{ Total } & \multicolumn{2}{|c|}{ Dutch } & \multicolumn{2}{|c|}{$\begin{array}{l}\text { Western } \\
\text { immigrants }\end{array}$} & $\begin{array}{l}\text { Non-western } \\
\text { immigrants }\end{array}$ \\
\hline Obs. & $\%$ & Obs. & $\%$ & Obs. & $\%$ & Obs. \\
\hline
\end{tabular}

\begin{tabular}{|c|c|c|c|c|c|c|c|c|c|}
\hline Age (average) & & 81734 & 24,89 & 74849 & 24,84 & 3261 & 25,55 & 3624 & 25,37 \\
\hline Grade (average) & & 79762 & 3,65 & 73005 & 3,66 & 3180 & 3,6 & 3577 & 3,44 \\
\hline \multirow[t]{5}{*}{ Mismatch } & No mismatch & 52243 & 63,79 & 48420 & 64,55 & 1899 & 58,16 & 1924 & 52,97 \\
\hline & Horizontal mismatch & 9066 & 11,07 & 8070 & 10,76 & 490 & 15,01 & 506 & 13,93 \\
\hline & Vertical mismatch & 9486 & 11,58 & 8794 & 11,72 & 337 & 10,32 & 355 & 9,77 \\
\hline & Double mismatch & 6943 & 8,48 & 6196 & 8,26 & 326 & 9,98 & 421 & 11,59 \\
\hline & Unemployed & 4166 & 5,09 & 3527 & 4,7 & 213 & 6,52 & 426 & 11,73 \\
\hline \multirow[t]{2}{*}{ Gender } & Male & 34243 & 41,87 & 31506 & 42,07 & 1362 & 41,74 & 1375 & 37,87 \\
\hline & Female & 47541 & 58,13 & 43384 & 57,93 & 1901 & 58,26 & 2256 & 62,13 \\
\hline Highest educational level & General secondary education & 42447 & 51,87 & 38861 & 51,85 & 1741 & 53,34 & 1845 & 50,85 \\
\hline \multirow{4}{*}{ before } & Pre-university secondary education & 12670 & 15,48 & 11851 & 15,81 & 541 & 16,57 & 278 & 7,66 \\
\hline & School-Based/Work-Based secondary vocational education & 22480 & 27,47 & 20305 & 27,09 & 808 & 24,75 & 1367 & 37,68 \\
\hline & Higher vocational education & 3394 & 4,15 & 3165 & 4,22 & 141 & 4,32 & 88 & 2,43 \\
\hline & Other & 847 & 1,03 & 764 & 1,02 & 33 & 1,01 & 50 & 1,38 \\
\hline \multirow[t]{10}{*}{ Sector of studies } & educational studies & 8211 & 10,03 & 7800 & 10,4 & 229 & 7,01 & 182 & 5,01 \\
\hline & educational studies in general subjects & 1533 & 1,87 & 1397 & 1,86 & 62 & 1,9 & 74 & 2,04 \\
\hline & teacher occupational subjects & 1516 & 1,85 & 1437 & 1,92 & 43 & 1,32 & 36 & 0,99 \\
\hline & pedagogic & 1649 & 2,01 & 1472 & 1,96 & 66 & 2,02 & 111 & 3,06 \\
\hline & art & 602 & 0,74 & 535 & 0,71 & 37 & 1,13 & 30 & 0,93 \\
\hline & social and cultural education & 357 & 0,44 & 318 & 0,42 & 20 & 0,61 & 19 & 0,52 \\
\hline & communicational studies & 2693 & 3,29 & 2364 & 3,15 & 158 & 4,84 & 171 & 4,71 \\
\hline & journalism & 880 & 1,07 & 813 & 1,08 & 36 & 1,1 & 31 & 0,85 \\
\hline & business administration & 4210 & 5,14 & 3836 & 5,11 & 132 & 4,04 & 242 & 6,66 \\
\hline & marketing and commercial economics & 5965 & 7,28 & 5264 & 7,02 & 297 & 9,1 & 403 & 11,1 \\
\hline
\end{tabular}




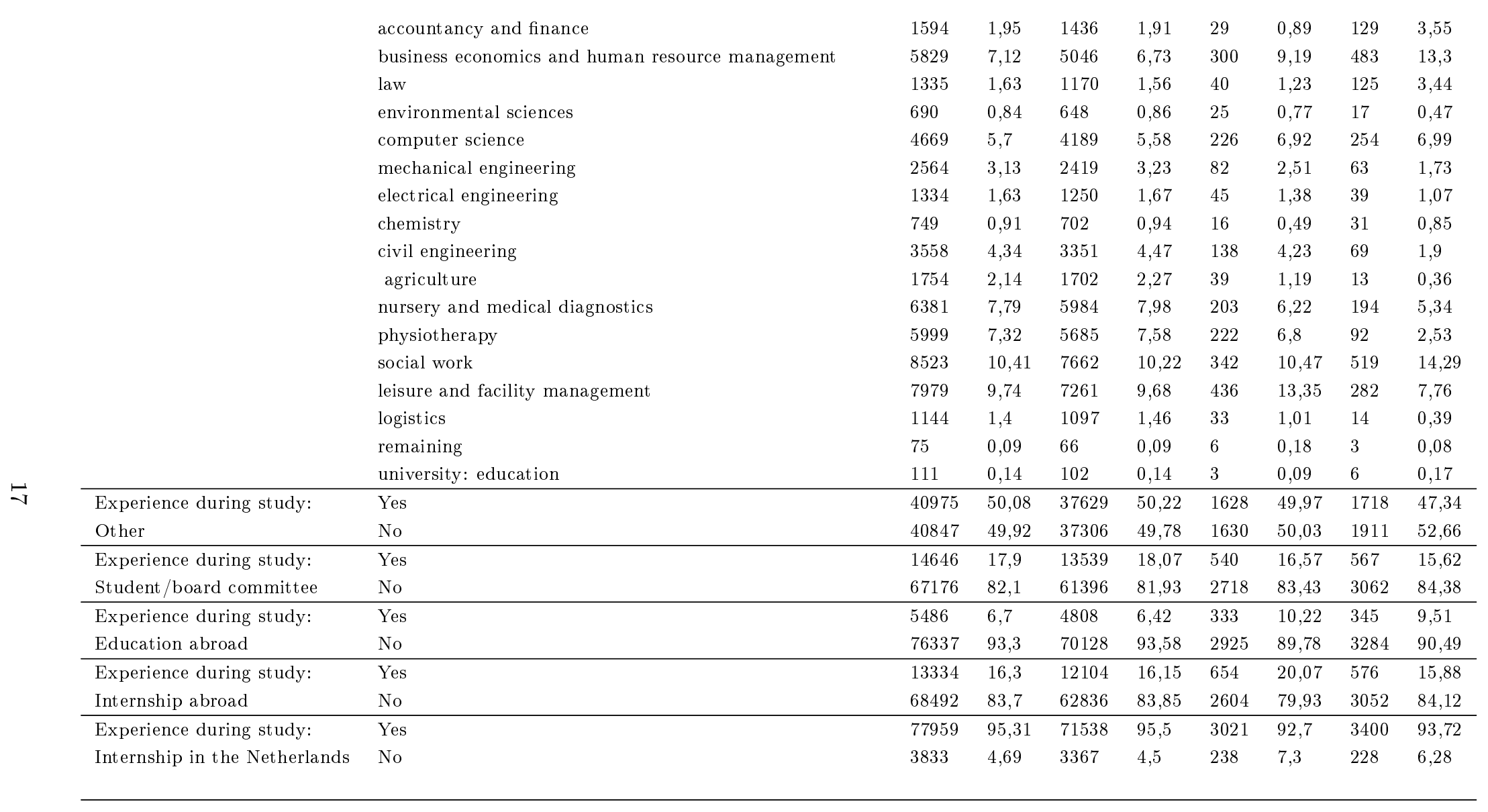




\subsection{Appendix B}

Figure 1: Plot of average marginal effects

\section{Average Marginal Effects with 90\% Confidence Interval}
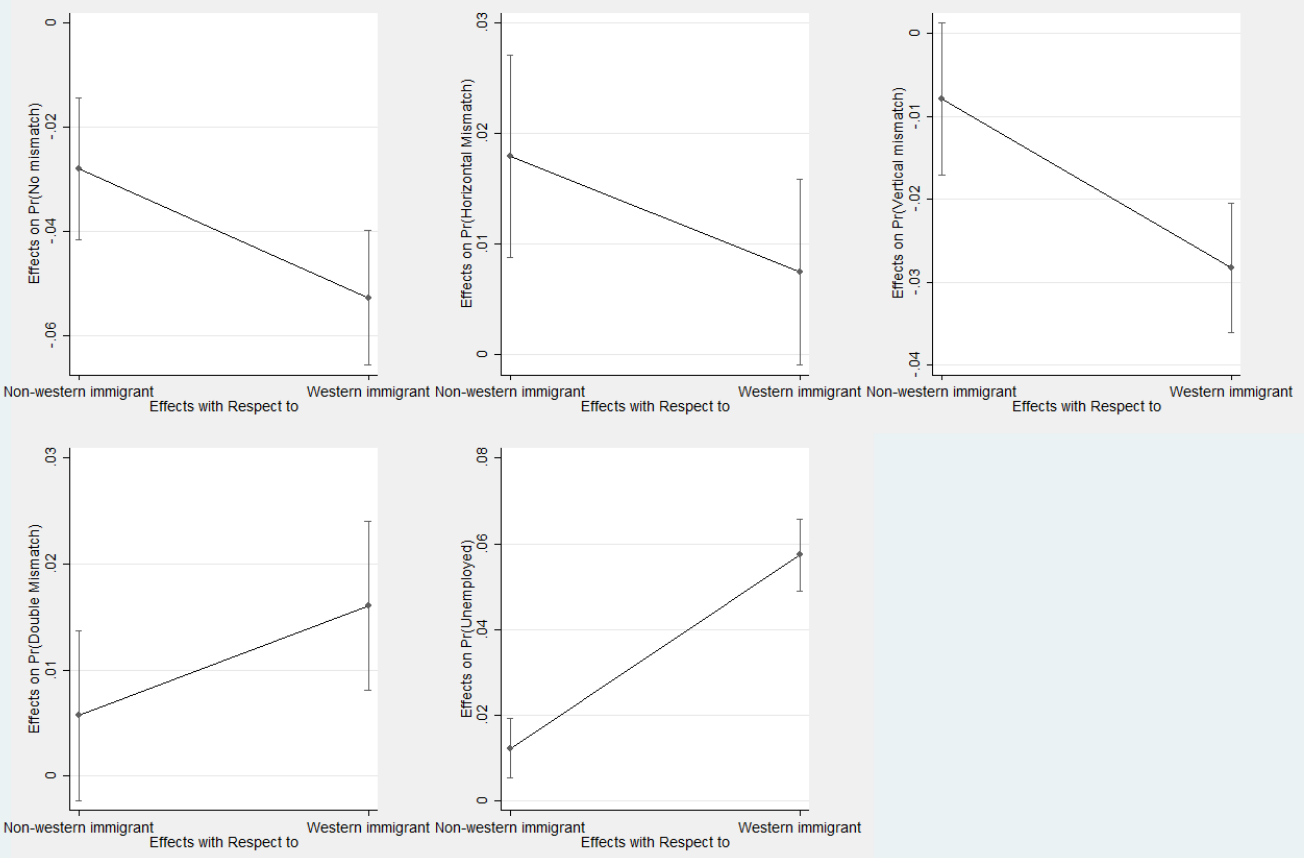